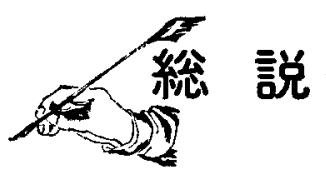

\title{
固体金属表面の熱力学 ——特に酸素吸着および酸化物の形成について
}

$\square$ 新居 和 嘉*

\section{1 は じめに}

近年，金属表面を清浄化し，それをある時間保持する ための真空技術，またその表面でおこる反忘を解析する ための種々の方法が開発されたため，金属表面につい て多くの研究がなされるようになってきた。たとえば LEED, AES による吸着相の構造解析や吸着種, 被覆 率の分析，また ESCA による吸着種の状態の解析など がそれである.その他，古い方法ではあるが接触電位差 の測定なども新しい超高真空装置の中で状態のわかった 表面について行われ，新しい結論が得られるようになっ てきた. しかしこれらの測定は一般に $77^{\circ} \sim 800^{\circ} \mathrm{K}$ 程度 の温度範囲で, ガス压も $10^{-9} \sim 10^{-6}$ Torr 程度で行われ ている.ガスとして酸素を考えた場合，このような条件 はほとんどの金属にとって酸化性のふんい気であり,し たがってこのような方法で測定された吸着 (adsorption), 吸蔵 (incorporation) の過程，また劣れに伴ら熱の出 入りは低温酸化 ${ }^{1)}$ の時間変化に対応するものであり, 熱 力学的に安定な吸着構造, 吸着熱をあらわすものではな w.

一方，固体金属表面の熱力学的量の測定も少数ではあ るが行われている．固体金属一ガス界面における熱力学 的量として最も重要なのは表面張力 $r$ と, 表面過剩量 (吸着量) $\Gamma$ である.純金属一酸素系の場合，これら 2 つの量は Gibbs の吸着等温式により次のように結びっ けられている。

$$
d r=-\Gamma_{\mathrm{o}} d \mu_{\mathrm{o}}
$$

\footnotetext{
* 金属材料技術研究所（東京都目黑区中目黒 2-3-12）
}

ここで $\mu_{0}$ は酸素の化学ポテンシャルである. 系は熱カ 学的に平衡状態にあるので酸素の化学ポテンシャルとし てガス相，金属一ガス界面に存在する吸着相，金属中に 固溶した相のうちのどれをとってもよいが，通常はガス 相中の酸素の化学ポテンシャル $\mu_{0}=\mu_{0}{ }^{0}+R T \ln P_{O_{2}}$ が 使われる.これを(1) 式に代入すると次式が得られる.

$$
d \gamma=-\Gamma_{\mathrm{o}} R T d \ln \mathrm{Po}_{2}
$$

したがってある酸素圧に扝ける金属の表面張力 $r$ を測定 すれば，その温度における平衡の酸素吸着量を求めるこ とができる、しかしこのような固体の表面張力の測定は 通常, 高温, 長時間を要し, しかも普通の金属, たとえ ば銅では $10^{-25} \sim 10^{-5} \mathrm{~atm}$ といら範囲で酸素珐を制御す る必要がある。このため高真空中で酸素を微量りークさ せてふんい気を調整するという方法ではこのような測定 は不可能である. 通常, このような範囲での酸素压の制 御は水素/水蒸気子ん、気中の平衡酸素圧を利用する が，このようなふんい気中の表面張力測定では，吸着平 衡にある酸素の吸着量は知ることができても, 酸素の吸 着状態，吸着熱などを知ることは困難である.

本稿では高温における表面張力の測定，また室温近傍 におけるLEEDによる酸素吸着の研究結果などをまと めて紹介し，それから固体金属一ガス界面における吸着 状態の変化を論ずることとする.

\section{2 酸素吸着による表面張力の変化}

固体の表面張力を測定する方法としてはクリープ法 (zero-creep method), 多相平衡法, 䢃開法など多くの 方法があるが2,3，クリープ法が最も広く使われ，それ 
による值が最も信頼されている*1.この方法は金属の細 線またははく（はくの方が表面積／体積の比を大きくと れるため低温まで測定できるが，応力状態の解析に不確 かさが多くなる）の下端に小さな荷重をかけて，ある子 んい気中で高温に保持する.このような条件下では金属 は Herring-Nabbaro クリープにより伸びるが,ある大き さの荷重のところでクリープ速度が 0 になる。これは表 面張力による圧縮応力と荷重による引張り応力がちょう ぞ等しくなった点に相当する（図 $1^{53}$ ). 表面張力rはこ の荷重

図 2 のよらに半径 $r$ の細線を考え，その表面張力を $r$

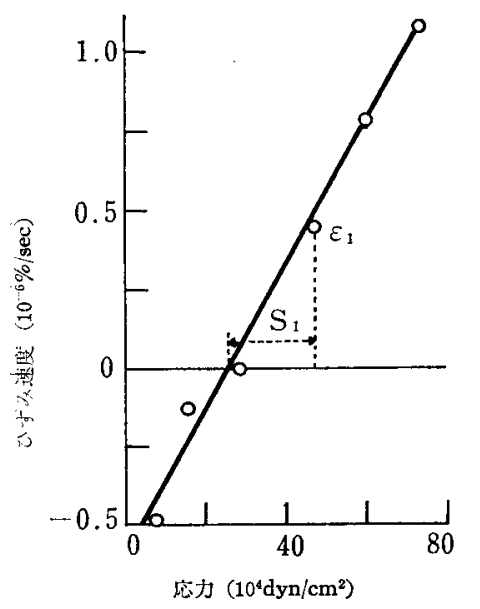

図 $1 \mathrm{Cu}-0.78 \mathrm{at} \% \mathrm{Sb}$ 合金のクリープ速度と 応力との関係(s), ヘリウム中, $950^{\circ} \mathrm{C}$

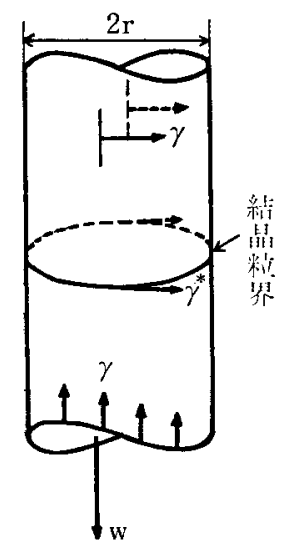

図 2 クリープ法による表面 張力の測定原理

とすると, 表面張力による細線の軸力向八の圧 縮応力 $\sigma_{\mathrm{x} x}$ は,

$$
\sigma_{\mathrm{xx}}=2 \pi r \gamma / \pi r^{2}
$$

また曲率半径 $r$ の円筒の円周に働らく静水圧 $P$ は,

*1 固体の表面張力测定い对する Bikerman“)の批判考参照されたい。

$$
P=\sigma_{y y}+\sigma_{z z}=(r / r+r / r)=2 r / r
$$

このような静水圧により生ずる軸方向への見かけの引張 り店力 $\sigma_{\mathrm{xx}}^{\prime}$ はポアソン比を $\nu(=0.5)$ とすると,

$$
\sigma_{\mathrm{xx}}^{\prime}-\nu\left(\sigma_{\mathrm{yy}}+\sigma_{z z}\right)=0.5 \times 2 r / r=r / r
$$

したがって細線の軸方向にかかっている全体の圧縮応力 林

$$
\sigma_{\mathbf{x x}}-\sigma_{\mathbf{x} \mathbf{x}}^{\prime}=2 \pi r r / \pi r^{2}-r / r=\pi r r / \pi r^{2}
$$

長さ $l$ の細線の中に $n$ 個の結晶粒界があり，その粒界 張力在 $r^{*}$ とすると $(6)$ 式汢次のよらになる.

$$
\begin{aligned}
& \sigma_{\mathbf{x x}}-\sigma_{\mathbf{x} \mathbf{x}}^{\prime}=2 \pi r r / \pi r^{2}-\left(r / r+n r^{*} / l\right) \\
& \quad=\pi r \gamma / \pi r^{2}-n r^{*} / l
\end{aligned}
$$

これが外部からかけた引張り応力 $w / \pi r^{2}$ と等しいとき $w / \pi r^{2}=\pi r \gamma / \pi r^{2}-n r^{*} / l, w=\pi r \gamma-\pi r^{2} n \gamma^{*} / l$

全体の軸方向の応力は 0 上なり，クリープ速度も0 とな

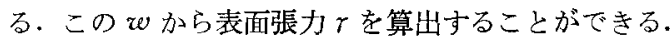

ここで求められた量は表面張力rである. 表面張力 $r$ は新しい表面を作るための可逆仕事として定義される が，固体の場合には表面積を抎げるために内部から表面 に原子をもってくる方法 (plastic strain) と，表面の原 子間距離を伸ばし拡げる方法 (elastic strain) の 2 つの 方法があり，それに対応して表面張力 (surface tension) と表面応力（surface stress）が定義されている6 \% . ク リープ法のように高温で非常に緩りした変形がおこる場 合には原子の移動が変形に追随でき，液体の場合と同じ よ5に表面張力が求められる.

さてこのような方法で固体金属の表面張力を測定する 場合, ふんい気の酸素圧を変化するとそれに対応して表 面張力も変化する．すなわち，表面張力を最も下げるよ うな吸着がおこる(一般に金属によって酸素，イオウな どは最も surface active な元素である).このような酸 素吸着による表面張力の変化についての Hondros ${ }^{93}$ の結

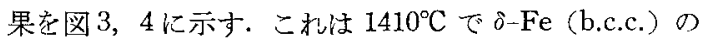
表面張力を種々の酸素圧つもとで測定した結果である。 図 3 にひずみ速度一応力の関係が示されているが，酸素 圧によるクリープ挙動の違いが明りょうに譛められる. 図4 はこれから求められた表面張力と酸素圧との関係で ある。この図を見ると奇妙な点に気がつかれることと思 う. 寸なわち $P_{\mathrm{O}_{2}} \sim 10^{-15}$ atm 付近に折れ点が現われ，バ ルクの $\mathrm{Fe} / \mathrm{FeO}$ の平衡酸素圧である $\mathrm{PO}_{2} \sim 10^{-9.6}$ atm で はむしろ滑かに連続しているということである。むし $P_{\mathrm{O}_{2}}<10^{-9.6} \mathrm{~atm}$ では表面は酸素の吸着相でおおわれてお り， $\mathrm{Po}_{2}>10^{-9 \cdot 6} \mathrm{~atm}$ では表面が酸化物でおうおわれている とすると不連続はこの位置に現われると期待される。し かし奏験結果ではそれより $10^{5} \mathrm{~atm}$ 程度低い酸素圧の点 で折れ点が現われている.このような現象は同じ著者 $ら^{107}$ による銅の表面張力の測定についても認められる. 図 5 にその結果を示すが,この場合には $\mathrm{Cu} / \mathrm{Cu}_{2} \mathrm{O}$ の平 衡酸素圧より 約 $10^{7} \mathrm{~atm}$ 程度低い酸素圧で表面張力に不 


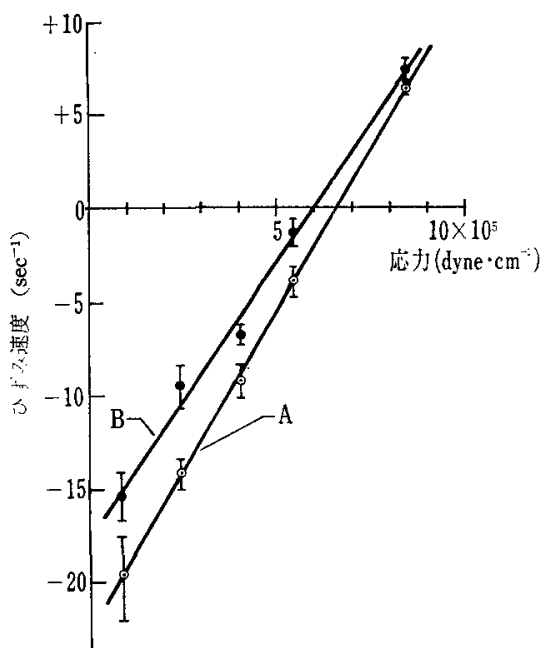

図 3 酸素压によるひずみ速度一応力閣僄の変化早 試料：私鉄位： 温 度: $1410^{\circ} \mathrm{C}$ 酸压素: $\mathrm{A}, P_{\mathrm{O}_{2}}=10^{-17} \mathrm{~atm}$ B, $P \mathrm{o}_{2}=10^{-10}$ atm

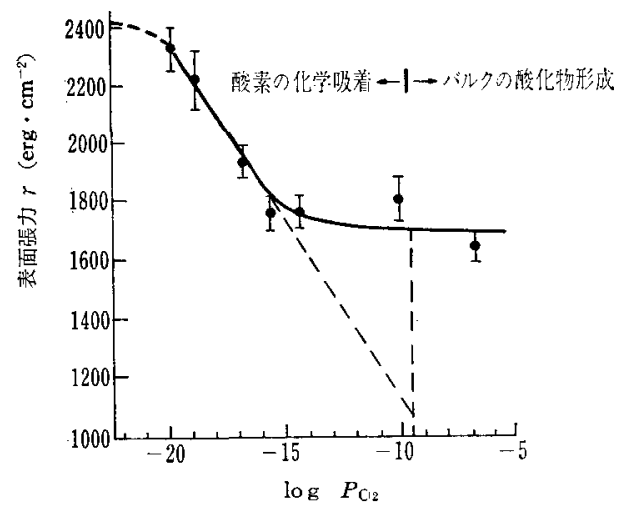

図 4 酸素代の関数としての鉄の表酒張力の変化9

連続が現われ，それは鉄の場合より顕著である。またこ の場合にも $\mathrm{Cu} / \mathrm{Cu}_{2} \mathrm{O}$ の平衡酸素圧の点ではむしろ滑か に変化している，なおここで求められた表面張力は測定 法からわかるようにある特定の結晶面についての值でな く平均化された值である。

さてすべての金属についてこのよらな表面張力一酸素 圧の関係が認められるかどうかは広い酸素圧の範囲にわ たっての実験が少いため不明ではあるが，金属に共通し た現象ではないかと考えられる。もしそうだとすると， 酸素ガスと平衡に存在する固体金属の表面は酸素圧によ って4つの状態に分類できるであろう（図 5 (b)). ま ず第１の状熊（StateＩ）は酸素圧が平衡酸素圧よりす っと低い領域で，酸素の吸着量も少い状態である. 次に 酸素圧が増加してくると酸素の吸着が多くなり，ほぼ一

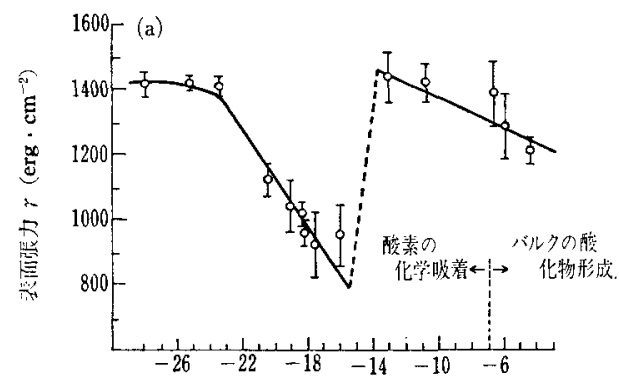

(b)

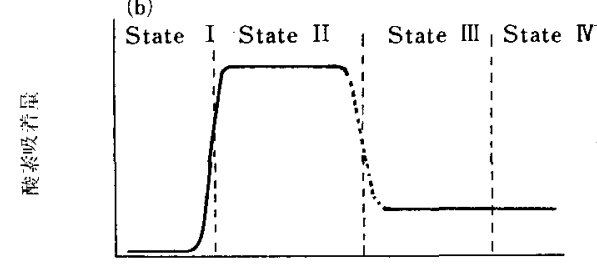

$\log P_{0_{2}}$

図 5 酸素仕による銅の表面張力および吸着量の変化 ${ }^{10 \gamma}$

訊橉: 純 $\mathrm{Cu}$ 沈

温度 : $927^{\circ} \mathrm{C}$

定となる (State II).ここでは表面張力は直線的に減少 する．さらに酸素圧が上昇すると不連続な変化がおこり State III となる.ここでは表面張力の変化の傾斜から考 えて State II より吸着量は少い。これまではバルクの酸 化物が形成されない領域であるが，さらに酸素圧が増加 するとバルクの酸化物が安定な領域にはいる(State IV). ここでは当然，表面は酸化被膜におおわれていると考え られるが，表面張力の值は前の State III から滑かにつな がっている.

このよらな酸素生による金属表面の状態の分類はすで に Bénard" によって一部行われている. 彼は faceting および吸着奏験から金属表面を（1）ガスと相互作用の ない領域, (2) 2 次元的化学吸着相起形成寸る領域,

(3) 3 次元的化合物を形成する領域の 3 つに分類して いる.しかし彼の分類による（2）の領域は不明確であ る.たとえば図 $6^{12)}$ に示すように鉄の表面に faceting

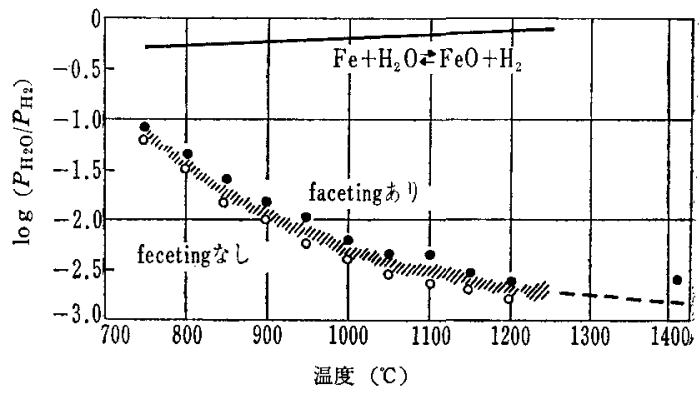

図 6 鉄の faceting についての状態図 ${ }^{12)}$ $1410 \mathrm{C}$ におけるの日は鉄の表偭張力に屈曲 点か現斺れる位置 (E.D. Hondros 
が生ずる $\mathrm{PO}_{2}$ と表面張力の測定で State II から State III に移る折れ点の $P_{\mathrm{o}_{2}}{ }^{9}$ とはよく一致している. この $\mathrm{P}_{\mathrm{O}_{2}}$ を Bénard は彼の（1）の領域と（2）の領域の境界と考 えたが，表面張力の測定結果から明らかな上うにこれ以 下の酸素圧ですでに酸素の吸着によるrの低下がおこっ ており，これ以前をガスと相互作用のない表面と考える ことはできない。

\section{3 各酸素圧領域における金属の 平衡表面状態について}

このような各酸素圧領域に対応して金属表面はどのよ らな状態にあるかを LEED などによる実験結果を参考 にしながら考察してみよう。

\section{1 State I}

この領域では酸素の吸着量は少く，表面は清浄な状態 にあると考えることができる．しかし金属の表面原子が 内部と同じ配列にあるかどらか明らかでない，自己表面 拡散係数の測定 ${ }^{13)}$, 熱力学的考察 ${ }^{14)}$ 加高温の固体金属 表面には 2 次元液体の存在も主張されている。いずれに してもこの領域ではガス分子と金属表面の相互作用は小 さく，酸素分子はほとんど弾性衝突をくり返しているで あろう。

\subsection{State II}

酸素圧が増加すると酸素分子と金属表面の間の相互作 用が大きくなり，衝突した酸素はある時間金属表面に滞 留するようになる。この領域では酸素の吸着量は多くな り，ほぼ一定の值を保つ。ここでいら吸着とはガス相と 平衡にある吸着であり，通常 LEED などで調べられて いる低温酸化の前駆状態としての吸着と法異なる。した がって金属一ガス分子間の相互作用，すなわち吸着熱も 異なるはずである，一般に酸素の吸着熱注安定な酸化物 の生成熱にほぼ等しいといわれている，表 1 に Brennan ら ${ }^{15}$ の吸着熱の測定結果を示す。これは金属の蒸着膜に 室温で酸素を吸着させたときの吸着熱であるが，酸化物 の生成熱と非常によく一致していることがわかる．しか しこの采件で測定されたものは低温酸化反応の生成熱で あり，よく一致しているのはむしろ当然であろう。ただ ここでロジウム, パラジウム, 白金だけは被覆率 $\theta$ も 1 以下であり，吸着熱も各酸化物の生成熱之異なる。これ はこれらの金属については酸化でなく，真の意味の化学 吸着熱が測定されたためと考えられるままた同じ著者 $ら^{16)}$ により， $77^{\circ} \mathrm{K}$ における $\mathrm{Ni} ， \mathrm{Co}$ 蒸着膜上一の酸素 の吸着はそれぞれ $84,70 \mathrm{kcal} / \mathrm{mole}$ と報告されている. この值は表 1 の室温での吸着熱よりかなり小さい，もし 低温で金属表面原子の移動がおそく，酸化物の形成が不 可能であったとすれ㥙，これらの值が真の吸着熱に近、 ものであるう。もしそうだとするとこの State II におけ
表 1 種々の金属表面への酸素の吸着熱と 酸化物の生成熱

\begin{tabular}{|c|c|c|c|c|c|}
\hline 金 属 & \begin{tabular}{|c} 
被覆率 \\
$(\theta)$ \\
最初の䠑 \\
夏穦上り
\end{tabular} & 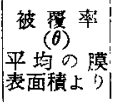 & $\begin{array}{l}\text { 最大吸者熱 } \\
\text { (kcal/mole) }\end{array}$ & $\begin{array}{l}\text { 安定な } \\
\text { 酸化物 }\end{array}$ & $\begin{array}{c}\text { 安定な } \\
\text { 酸华物 } \\
\text { の生成熱 } \\
\text { (kcal/mole) }\end{array}$ \\
\hline Ti & 6.00 & 8.56 & 236 & $\mathrm{Ti}_{3} \mathrm{O}_{5}$ & 235 \\
\hline $\mathrm{Cr}$ & 1.75 & 2.55 & 174 & $\mathrm{Cr}_{2} \mathrm{O}_{3}$ & 180 \\
\hline $\operatorname{Mn}(\mathrm{a})$ & 1.04 & $3.03\}$ & 150 & $\mathrm{MnO}$ & 153 \\
\hline (b) & 1.52 & $11.8\}$ & 100 & $\mathrm{IVH}_{2} \mathrm{U}_{3}$ & 103 \\
\hline $\mathrm{Fe}$ & 3.39 & 4.74 & 136 & $\mathrm{Fe}_{3} \mathrm{O}_{4}$ & 134 \\
\hline Co & 1.45 & 2.28 & 100 & $\mathrm{Co}_{3} \mathrm{O}_{4}$ & 102 \\
\hline $\mathrm{Ni}$ (a) & 1.65 & $2.56\}$ & 107 & $\mathrm{NiO}$ & 116 \\
\hline (b) & 1.95 & $2.55 \mathrm{~J}$ & & & \\
\hline $\mathrm{Nb}$ & 2.45 & 3.81 & 208 & $\mathrm{Nb}_{2} \mathrm{O}_{5}$ & 182 \\
\hline Mo & 1.27 & 1.41 & 172 & $\mathrm{MoO}_{2}$ & $13 I$ \\
\hline $\mathrm{Rh}$ & 0.84 & 0.97 & 76 & $\mathrm{Rh}_{2} \mathrm{O}$ & 48 \\
\hline$P d$ & 0.65 & 0.74 & 67 & $\mathrm{PdO}$ & 42 \\
\hline $\mathrm{Ta}$ & 2.24 & 3.20 & 212 & $\mathrm{Ta}_{2} \mathrm{O}_{5}$ & 193 \\
\hline W & 1.15 & 1.33 & 194 & $\mathrm{WO}_{2}$ & 134 \\
\hline $\mathrm{Pt}$ & 0.62 & 0.63 & 67 & $\mathrm{PtO}$ & 34 \\
\hline $\mathrm{Al}$ & 6.78 & 4.41 & 211 & $\mathrm{Al}_{2} \mathrm{O}_{3}$ & 266 \\
\hline
\end{tabular}

る吸着熱は $70 \mathrm{kcal} / \mathrm{mole}$ 程度で，あるいは金属の種類 にあまり依存しない值であることもありうる。

この State II における酸素の吸着量を図 4,5の直線 部分の傾斜より Gibbs の吸着等温式を利用して求める と，鉄，銅とも(酸素原子／表面金属原子）の比にして 約 0.25 といら值が得らえる. Pignocco ら ${ }^{177,18)}$ は鉄の

(001)，(011）面を室温で低圧の酸素に露出した場合の 構造変化を LEED により追跡し，報告している，その 結果, (011) 面で $0.2 \mathrm{~L}$ (露出の程度を表わす単位で 1 Langmuir $=10^{-6}$ Torr-sec) までは（011）パターンのみ でただ background だけが高くなる，さらに露出が多く なると新しいパターンが現われ，これは $\mathrm{c}(2 \times 2)-\mathrm{O}$ 構造*2をるつと報告している.この構造は酸素の被覆率 にして $1 / 4$ に相当する．また鉄の $(001)$ 面では最初に現 われる規則的な構造は酸素の被覆率にして $1 / 2$ である. また Ni の（110）面を酸素に露出した場合，現われる 最初の規則構造は $(3 \times 1)-\mathrm{O}\left[\frac{1}{3}\right]$ で, 被覆率は $1 / 3$ で あると報告されている ${ }^{20)}$ 。これらの結果から酸素の規則 的な吸着構造が現われるのは被覆率が $1 / 4$ 程度からであ り，この值は表面張力の測定結果から求められた State エに扔ける被覆率と一致する。しかし，表面張力の測定 は多結晶体について行われたものであり，しかも融点に 近い高温で測定されているので被覆率 $1 / 4$ の吸着構造が この温度まで安定に存在しらるかどうか疑問である。ま た結晶面による異方性の一つの指標である faceting がこ の領域でおこらないといら結果 ${ }^{10), 12)}$ から,この領域での 酸素吸着は均一でしかも不規則な構造ではないかと考え られる.そしてこのような吸着相は金属の表面上に存在 し，金属表面に組み込まれていない（unreconstructed） であるう。

\footnotetext{
\#2 夷面の 2 次元的構造の表忈法についてはWood ${ }^{192}$ を参照。
} 


\section{3 State III}

この領域では Gibbs の吸着等温式から計算される吸 着量は前の State II に比較して減少し, faceting も著 しくなる、酸素圧が増加して表面に存在する酸素量が減 少することは通常考えられないのでここで表面の状態に 変化が括こったと考えるのが妥当であるう。この場合， 考えられる変化としては吸着根から酸化相への変化であ る.しかしこの領域はまだいわゅる金属の酸化還元の平 衡酸素圧以下であり，バルクの安定な酸化物は存在しえ ないここで考えられるのは表面だけに存在する酸化物, すなわち表面にだけ形成され，内部に成長していかない 酸化物である.熱力学的に考えれば純金属がその酸化物 之共存しらるのは一定の平衡酸素圧の点のみであり, そ れより酸素圧が高いと, 酸化は内部にまで進行し, 長時 間㧠けば全体が酸化物汇変化してしま5。しかしこの State III においては内部は金属が安定であり，表面牥酸 化物が安定（その構造はどうであれ）と考えられる領域 である.このようなことは表面が表面張力の分だけ過剩 のエネルギーをもっていることを考えれば容易に理解さ れる. 表面張力溔力学的に新しい表面を作るための可 逆仕事として定義されるが，新しい表面を作るといらこ とは内部から表面一原子を持っていくことに相当する. すなわち内部から表面一原子をもっていくために要する 仕事である.このことは表面の原子が内部の原子より表 面張力の分だけ高、化学ポテンシャルを持っていること に相当する.このような高い化学ポテンシャルまたは活 量をもった表面ではより低い酸素圧ですでに酸化がはじ まることは十分推測されるが，それがどの程度低い酸素 圧ではじをるか明らかでない，それを知るためには生 成した酸化物の組成や化学ポテンシャルまたは活量を知 ることが必要になるが，表面にだけ存在する酸化物はそ れらが明らかでないので，このよらな計算は不可能であ る.もし Fe の場合, 生成する酸化物がバルクと同じ FeOであるとすると， $1410^{\circ} \mathrm{C}$ に叔いて $10^{5} \mathrm{~atm}$ 低い酸素

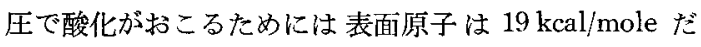
け高いギブス・エネルギーを持っていなければならない。 図 4 から酸化がおこる直前の表面張力の值 $1700 \mathrm{erg} / \mathrm{cm}^{2}$ を表面の一層だけの過剩のギブス・エネルギーとすると $17 \mathrm{kcal} / \mathrm{mole}$ となり比較的近い值になる.しかしこのよ うな計算にはなんら正当性はない。

さて Germer ら ${ }^{21}$ は Ni 酸素露出したときの表面 構造の変化を詳細に検討している，O/Ni が $5 \times 10^{-4}$ 以 上の酸素を含んだ試料では表面の $(2 \times 1)-\mathrm{O}\left[\frac{1}{2}\right]$ 構造 が安定であり，水素で表面を一度還元しても，1200攵， 高真空中で加熱するとふたたび $(2 \times 1)$ 構造が現われるこ とを報告しているすすなわち，酸素を $5 \times 10^{-4}$ 以上含ん だ試料では表面の安定相は $(2 \times 1)-\mathrm{O}\left[\frac{1}{2}\right]$ 構造であ り，酸素の被覆率が $1 / 2$ の状態である。これは $\mathrm{Ni}$ 内部
に固溶した酸素量がある程度以上になると表面に $(2 \times 1)$ $-\mathrm{O}\left[\frac{1}{2}\right]$ 構造をもった $\mathrm{NiO}_{0.5}$ を析出し, それと固溶 した酸素が平衡に存在することを意味する，通常，合金 の析出において結晶粒界が析出 siteになるといわれてい るが，それと同じ意味で酸素の固溶相から酸化物が析出 寸る場合, 表面が析出site になりそこに低酸素濃度で優 先的に 2 次元的酸化物が析出するのであるう. Germer 注 $\mathrm{O} / \mathrm{Ni}=5 \times 10^{-4}$ という值は $\mathrm{Ni}-\mathrm{O}$ 系状態図に扮いて 酸化物と平衡に存在する酸素の固溶量上近似的に一致す ることをのべているが，もし表面への析出を問題とする 場合にはもっと低い值まで析出は可能であるはずであ る.すなわち $\mathrm{Ni}$ 表面のみの析出を考える場合には，状 態図は図 7 の点線のようになるであろう。

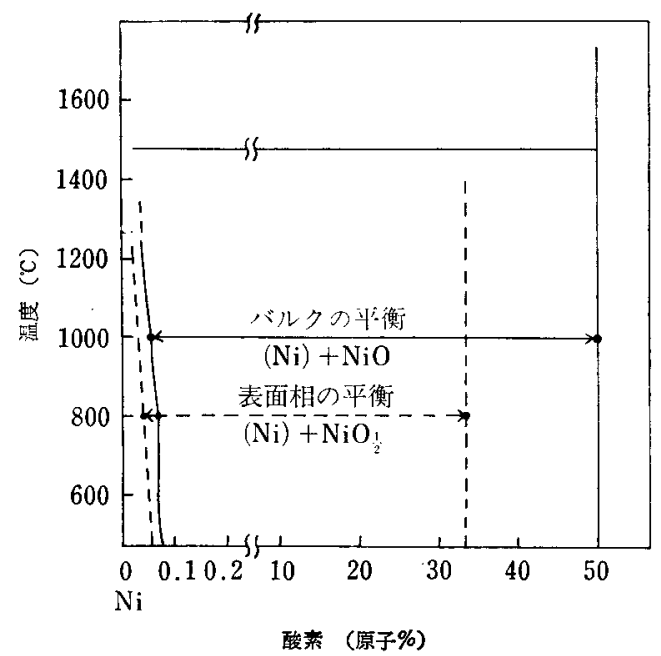

図 7 Ni-O 系のバルクおよび表面相の状態図 点線の位置は正確には不明

これらのことから考えて，この State III における金 属表面はすでに酸化物（その構造はバルクの酸化物と異 なる）によりおおおれていると考えてもよいであるう。 すなわち表面に存在する酸素は表面の格子の中に組み込 まれて規則的な配列をしており (reconstructed) それは 金属内部に固溶した酸素と平衡にある。これは酸化物と 呼んでもよいが 2 次元的であり，その酸素圧では 3 次元 的に成長することはありえない。

\subsection{State IV}

この領域では熱力学的にいって酸化物が安定であり, 表面は当然酸化被膜に㧍㧍われているである5．ESCA に上る研究 222 24) によれば酸化物上で，酸素の 2 ないし 3つのピークが認められている.これはおのおの酸化物 格子中の酸素 $\mathrm{O}^{2-}$, 表面の水酸化イオン $\mathrm{OH}^{-}$中の酸素, および化学吸着された酸素 O- とされている.したがっ て State III 以降の状態で Gibbs の吸着等温式から求めら れる吸着量はこのような酸化物表面に化学吸着した酸素 
と考えることができるであろら．

\section{4 その他の方法による金属表面の研究}

以上述べた方法による表面研究のほか多くの方法によ る研究がなされている。たとえば接触電位差の測定, 付 着確率の測定などがそれである。

$\mathrm{Hall}, \mathrm{Me}^{25)}$ \& $\mathrm{Fe}, \mathrm{Co}, \mathrm{Mn}$ の接触電位差を室温で 測定し,その変化から酸素への露出が少い場合 $(<2.4 \mathrm{~L})$ には酸素の化学吸着が抽こり, 露出が増加すると $(6 \mathrm{~L})$ 酸素の格子への組みこみがおこり，さらに增加すると酸 化物が形成されると推定している。

また Horgan, King ${ }^{26)}$ は $\mathrm{Ni}$ の付着確率の測定から $1.5 \mathrm{~L}$ 以下では $\beta^{\prime}$ とよばれる末解離の酸素の不規則な 吸着相が存在し（被覆率 $\theta<1 / 4$ )さらに露出を増加する と $\beta$ と呼ばれる規則的な吸着構造 $(\theta<1)$ に変化するこ とをのべているまた鉄についても同様な測定を行いよ り複雑な結果を得ているが吸着初期の変化についての解 䣋注同でである。

Horgan, Dalins ${ }^{27}$ はAES によるNi 表面の研究か ら, 先の Horgan, King ${ }^{26)}$ の付着確率の結果を支持する 結果を得た.しかし $\theta<1$ の範囲内では酸素または $\mathrm{Ni} の$ ピークのケミカル・シフトは認められず， $250 \mathrm{~L}$ 以上に なって始めてシフトはあらわれる。

このほか酸素中 $800^{\circ} \mathrm{C}$ で加熱した銀の表面には酸化物

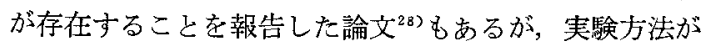

明確でないためここで議論することはできない，

また長, 井上 ${ }^{29}$ は溶融鉄の中への窒素の溶解速度を測 定した.それによると鉄中の酸素またはイオウは溶湯の 表面に吸着し, その吸着相がほぼ $\mathrm{FeO}$ また $\mathrm{FeS} の$ 組 成に等しくなるような溶湯中の酸素またはイオウ濃度に

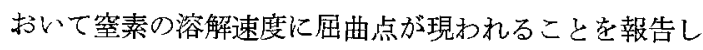
ている.この研究は固体でなく, しかも表面状態を測定 するための実験でもないが，固体の吸着と対応させて考 えれば興味ある結果である.

\section{5 まとめ}

以上論じてきたことをまとめてみると図 8 のようにな る.すなわち

State I ：酸素圧が平衡酸素圧よりずっと低い領域 で，酸素分子はほとんど弾性衝突している.

State II ：酸素圧が高くなり表面原子と酸素分子との 間に相互作用が生じ,酸素が表面に滞留するようになる. このときの酸素はまだ金属格子の中に組み込まれておら ず (unreconstructed) 不規則な配列をしているだろう。

State III：さらに酸素圧が高くなると表面の酸素は格 子の中に組み込まれ (reconstructed) 規則的な配列をす
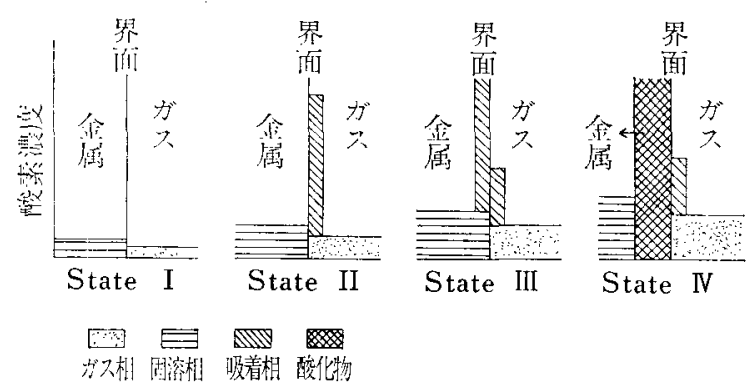

四 8 酸素压による金属表面の状態の变化

るようになる。この状態は表面だけの性質についていえ ばすでに酸化物といらこさができる。

State IV :さらに酸素圧が高くなり平衡酸素圧をこす と表面は酸化物被膜でお㧍われ，それに少量の酸素が化 学吸着したという状態に䚺る。

このよらな各領域閒の変化は変態ともいえるよらな比 較的シャープな境界をっているようである。

一般に吸着という言葉は熱力学的に平衡にある吸着 と, 反忘の前駆段階としての吸着と二種類の意味に使わ れている．話者固体金属上酸素の系に限って考えると酸 化の前駆段階としての吸着は Germer ものべているよう に酸化の開始と非常に密接に関連しており，それらの分 離は単なる定義の問題でしかない，一方，ガス相および 固溶相と平衡にある吸着も別の意味でじこまでを吸着上 いらか問題があるようである・またここでは結晶方位に よる異方性，同一面内での不均一性などを無視し，問題 を非常に単純化して考えてきたが，より詳細には当然こ れらも考慮しなけ机ばならないであるら。

\section{文献}

1）低温酸化一般についてはたとえばF.P. Fehlner, N.F. Mott, Oxi dation of Metals 2, 59 (1970), 老参照.

2) H. Udin, "Metal Interfaces", p. 114 (1952), ASM.

3）笛木和雄, 表面 10,639 (1972).

4) J.J. Bikerman, Phys. Stat. Sol. 10, 3 (1965).

5) M.C. Inman, D. McLean, H.R. Tipler, Proc. Roy. Soc. London A 273, 538 (1963).

6) C. Herring, "Structure and Properties of Solid Surfaces", ed. by R. Gomer, C.S. Smith, p.5 (1953), Univ. Chicago Press.

7) W.W. Mullins, "Metal Surfaces: Structure, Energetics, Kinetics", p. 17 (1963), ASM.

8) P.R. Couchman, W.A. Jesser, D. Kuhlmann-Wilsdorf, J.P: Hirth, Surface Sci. 33, 429 (1972).

9) E.D. Hondros, Acta Met. 16, 1377 (1968).

10) E.D. Hondros, M. McLean, C.N.R.S. Conference Proceedings (No187), "Structures et Propriétés des Surfaces des Solides", (1970); E.D. Hondros, M. McLean, Nature 224, 1296 (1969); M. McLean, E.D. Hondros, J. Material Sci. 8, 349 (1973).

11) J. Bénard, "Oxidation of Metals and Alloys", p 1 (1971), ASM.

12) J. Moreau, J. Bénard, Acta Met. 10, 247 (1962).

13) G.E. Rhead, Surface Sci. 15, 353 (1969); 22, $223(1970)$; H.P. Bonzel, N.A. Gjostein, ibid. 22, 216 (1970).

14) C.Gurney, Proc. Phys. Soc. 62, 639 (1949). 
15) D. Brennan, D.O. Hayward, B.M.W. Trapnell, Proc. Roy. Soc. London A 256, 81 (1960).

16) D. Brennan, M.J. Graham, Diss. Faraday Soc. 41, 95 (1966).

17) A.J. Pignocco, G.E. Pellissier, I. Electrochem. Soc. 112, 1188 (1965).

18) A.J. Pignacco, G.E. Pellissier, Surface Sci. 7, 261 (1967).

19) E.A. Wood, J. Appl. Phys. 35. 1306 (1964).

20) L.H. Germer, J.W. May, R.J. Szostak, Surface Sci. 8, 430 (1967).

21) J.W. May, L.H. Germer, ibid. 11, 443 (1968).
22) T. Robert, M. Bartel, G. Offergold, ibid. 33, 123 (1972).

23) G. Schön, S.T.Lundin, J. Electron Spectrosc. 1, 105 (1972/ 73).

24) K.S. Kim, R.E. Davis, ibid. 1, 251 (1972/73).

25) G.K. Hall, C.H.B. Mee, Surface Sci. 28, 598 (1971)

26) A.M. Horgan, D.A. King, ibid. 23, 259 (1970).

27) A.M. Horgan, I. Dalins, ibid. 36, 526 (1973).

28) D.E. Davies, Nature 179, 1293 (1957).

29）長 隆餙，井上道婎，鉄上鎆 54，19（1968）。

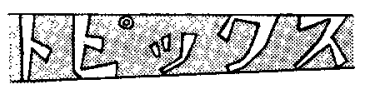

\section{電気化学基礎講習会 「電気化学の基礎理論とその忍用」}

電気化学協会東海支部では昨年 10 数年ふりに電気化学 基礎講習会「電気化学測定法入門」を開き, 多数の熱心 な参加者を得て盛大で実り多きものとなりましたが，今 年孔各方面からまた是非にとの強い要望があり, 引き続 いて「電気化学の基礎理諭とその応用」といら講習会を 8月28，29日の 2 日間名古屋で開催いたしました。

電気化学関係の講習会は各地で毎年数多々開催されて おりますが, 電気化学の基礎については皆無のため, 電 気化学を広く気やすく利用され、る技術者の養成の目的で 電気化学の理論党やさしく解説し, かつ実際的な応用と 関係づけた講習会としました。したがって，この講習会 は電気化学の専門家を対象としなくむしろ他の専門分野 また仿これから電気化学を勉強しようとする方々を対象 しいたしました、テーマを4つに分け，まず基礎的な講 義をし,つぶいてそれに直接関倸する応用的な講義を組 み合わせて行いました・とりあげたテーマは次の4つで †.

1. 電極電位, $\mathrm{pH}$ おょよ゙イオン電極

2. 過電圧拉上び混成電位, 腐食防食

3. 電解質溶液, イオン交捠膜によるメッキ液の処理
4. 電気化学的分析法, 用水および排水の電気化学的 測定法

聴講者の所属は化学はもとより電気, 機械、金属関保 と多方面にわたり，また專門分野も多種多椂であるため に，基整的な講義の程度をどのあたりに焦点をあわせる かが問題になりましたが，難解な理論る実際的な応用と 関係ずけることによりできるだけ多くの㯖講者に理解し ていただくように努力いたしました。

從来, 電気化学はある特别の分野の研究者, 技術者の みが専門的に研究したり技術開発索行うもので，一般の 企業の技術者には無縁のもののごとく思われていたため か，電気化学と㐫まり関係のない企業におい下電気化 学の専門家はいない傾向がみうけられます。しかし, 最 近で注, 環境管理, 新材料の開発等において電気化学的 手段が頻繁に用いられるようになったにもかかわらず， 電気化学の専門家がいなく，また他の分野の人々も電気 化学法難解であると考え手をださないために、き的て 初歩的な問題で困っている企業が数多くあることが，こ の講習会を通してわかりました.

電気化学的手段は今後益々多方面で利用されるものと 思われますので，今後ともこのような基䃈的な講習会が 必要と考えられます。な拉最後に, 本講習会汇注東海地 区以外加 $1 / 3$ 以上む参加されたことをつけ加えておき ます。

(基礎講習会世話人 伊藤要, 山本治) 